\title{
Pengaruh Intellectual Capital Terhadap Kinerja Perusahaan
}

\author{
Victoria dan Nuryasman MN \\ Program Studi Manajemen Fakultas Ekonomi Universitas Tarumanagara, Jakarta \\ Email:vctoriabong@gmail.com
}

\begin{abstract}
The purpose of this study is to analyze the effect of human capital, structural capital, and human capital on firm performance of retail trade companies listed on the Indonesia Stock Exchange in the 2014-2018 period. This study uses a sample selection technique in the form of purposive sampling. The sample in study were 18 samples in total. This study uses a descriptive research design with a quantitative approach. The results showed that structural capital and relational capital do not have a significant influence on ROA and negatively affect ROA. Meanwhile, human capital has a positive and significant influence on ROA.
\end{abstract}

Keywords: Human capital, structural capital, relational capital, ROA, firm performance

\begin{abstract}
Abstrak: Tujuan penelitian ini adalah untuk menganalisis pengaruh human capital, structural capital, dan human capital terhadap kinerja perusahaan pada perusahaan retail trade yang terdaftar di Bursa Efek Indonesia periode 2014-2018. Penelitian ini menggunakan teknik pemilihan sampel berupa purposive sampling. Sampel dalam penelitian ini berjumlah 18 sampel. Penelitian ini menggunakan desain penelitian deskriptif dengan pendekatan kuantitatif. Hasil penelitian menunjukkan bahwa structural capital dan relational capital tidak memiliki pengaruh signifikan terhadap ROA serta berpengaruh negatif terhadap ROA. Sedangkan, human capital memiliki pengaruh positif dan signifikan terhadap ROA.
\end{abstract}

Kata kunci: Human capital, structural capital, relational capital, ROA, kinerja perusahaan

\section{LATAR BELAKANG}

Pada dekade pertama abad ke-21, terjadi perubahan dalam hal booming dan fase resesi yang dipercayai bahwa fase-fase siklus bisnis tersebut berdampak pada nilai perusahaan, baik yang berskala besar maupun kecil dengan persaingan yang semakin kompetitif (Kumar, Colombage, \& Rao, 2017). Bagi perusahaan yang tidak mampu menciptakan keunggulan kompetitif, maka kinerja perusahaan tersebut akan menurun yang dapat berdampak pada pendapatan perusahaan tersebut di mana hal ini dapat membuat perusahaan tersebut mengalami financial distress.

Berdasarkan data dari databoks.katadata.co.id, dapat disimpulkan bahwa perusahaan retail trade di Bursa Efek Indonesia mengalami kinerja perusahaan yang menurun. Berdasarkan laporan keuangan emiten yang telah dipublikasikan di Bursa Efek Indonesia dan diolah Katadata.com, ditemukan hasil bahwa 10 perusahaan retail trade yang tercatat pada tahun 2017 mengalami pertumbuhan penjualan yang semakin lambat jika dibandingkan dengan tahun 2013. Penurunan pertumbuhan penjualan paling besar terjadi pada PT Electronic City Indonesia Tbk (ECII), yaitu mencapai lebih dari 3.100 basis poin (bps) dari 
40,69\% pada 2013 menjadi 9,55\% pada 2017. Sementara PT Ace Hardware Indonesia Tbk (ACES) mengalami penurunan pertumbuhan penjualan paling rendah, yaitu $53 \mathrm{bps}$ dari $20,85 \%$ pada 2013 menjadi $20,31 \%$ pada 2017. Bahkan tiga perusahaan retail trade seperti PT Ramayana Lestari Tbk (RALS), PT Hero Supermarket Tbk dan PT Matahari Putra Prima Tbk (LPPF) penjualannya mengalami penurunan pada tahun lalu dari tahun sebelumnya. Total penjualan 10 perusahaan retail trade berdasarkan data di atas pada 2013 mampu mencatat pertumbuhan lebih dari $21 \%$ dari tahun sebelumnya, tetapi pada 2017 hanya tumbuh $6,41 \%$ dari tahun sebelumnya. Hal ini menunjukkan bahwa terdapat masalah dalam kinerja perusahaan retail trade selama beberapa tahun terakhir.

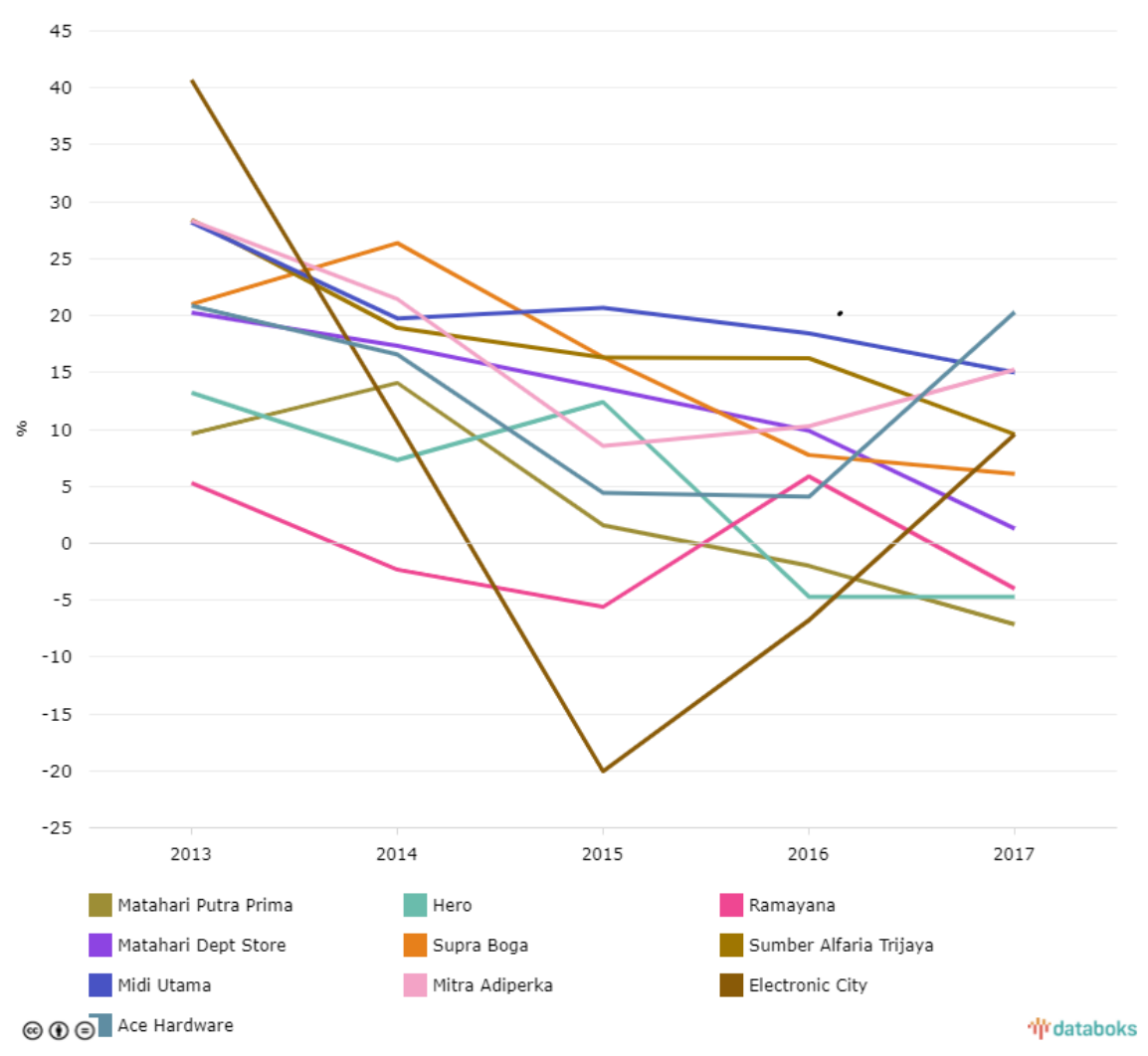

Gambar 1.1

Pertumbuhan Penjualan Emiten Ritel

di Bursa Efek Indonesia Tahun 2013-2017

Pada sebuah perusahaan sering terjadi konflik antara agen dan principal (teori agensi) karena adanya perbedaan kepentingan antara kedua belah pihak. Hal ini dapat dikarenakan perusahaan tidak memperhatikan sumber daya yang berkaitan dengan kinerja perusahaan, seperti human capital (tenaga kerja), structural capital (struktur perusahaan), dan relational capital (hubungan perusahaan dengan pihak ekseternal) di mana agen memiliki lebih banyak informasi dan pengendalian mengenai hal tersebut. Hal ini menyebabkan asimetri informasi (signaling theory) antara kedua belah pihak sehingga terjadi perbedaan pendapat dan tujuan. Dalam kasus seperti ini, laporan intellectual capital memiliki manfaat bagi perusahaan dalam menyediakan lebih banyak informasi kepada publik untuk lebih memahami kondisi perusahaan dan strategi yang dikembangkan oleh 
perusahaan melalui penggunaan intellectual capital. Perusahaan perlu memanfaatkan sumber dayanya secara tepat yaitu penggunaan intellectual capital secara tepat agar memiliki keunggulan kompetitif yang berkelanjutan, seperti pengukuran dan pemanfaatan yang tepat mengenai modal intelektual dan potensi intelektual seperti human capital dan structural capital (resource-based theory). Sinyal positif dari perusahaan akan mendapatkan respon positif pula oleh pengguna informasi tersebut. Suatu sinyal akan dapat dipercaya hanya jika perusahaan yang dikategorikan buruk tidak dapat mereplikasi perusahaan yang dikategorikan baik dengan mengirimkan sinyal atau biaya yang sama untuk mereplikasi sinyal yang lebih tinggi untuk perusahaan yang dikategorikan buruk, sehingga mereka merasa tidak ada manfaatnya untuk meniru sinyal-sinyal tersebut (Mantari \& Nuryasman, 2017). Informasi sangat penting bagi perusahaan untuk menggambarkan keadaan perusahaan kepada publik. Hal ini akan meningkatkan kepercayaan stakeholders terhadap perusahaan yang akan diinvestasikan (stakeholders theory). Intellectual capital merupakan bagian dari komunikasi perusahaan dengan stakeholders-nya, yaitu dengan mengendalikan kemampuan dan modal yang dimiliki sehingga pemanfaatannya dapat meningkatkan kinerja perusahaan secara keseluruhan. Contohnya seperti relational capital, di mana modal perusahaan dalam bentuk hubungan baik antara perusahaan dengan pihak luar (stakeholders) yang akan menciptakan nilai tambah perusahaan di mata pelanggan.

Intellectual capital diakui sebagai salah satu faktor umum yang dapat mempengaruhi kinerja perusahaan. Intellectual capital memiliki peran yang sangat penting dalam hal inovasi, daya saing, pertumbuhan produktivitas, dan kinerja perusahaan (Susanto, 2017). Menurut Susanto (2017), manajemen Intellectual capital yang efektif mampu mempengaruhi kinerja perusahaan dan produktivitasnya. Intellectual capital dapat diartikan sebagai gabungan dan sinergi antara keahlian, pengetahuan, kemampuan belajar, pengalaman, hubungan, proses, penemuan, inovasi, keberadaan pasar dan pengaruh masyarakat (Kanchana \& Mohan, 2017). Intellectual capital ini memiliki tiga dimensi, yaitu human capital yang berdasarkan sumber daya manusia, structural capital yang berdasarkan sumber daya di luar pengetahuan yang mengacu pada komposisi dan struktur perusahaan, dan relational capital yaitu hubungan antara perusahaan dengan pihak luar.

Menurut Khan, Humayun, dan Sajjad (2015), human capital yaitu pengetahuan serta kemampuan yang dimiliki anggota organisasi membantu mereka untuk mengidentifikasi dan memperoleh sumber daya bermanfaat lainnya serta menemukan dan mengeksploitasi peluang bisnis yang pada akhirnya dapat meningkatkan kinerja perusahaan terkait. Jika diperhatikan, kebutuhan akan sumber daya manusia yang berkualitas saat ini semakin meningkat seiring dengan semakin ketat persaingan dalam perekonomian dunia (Nuryasman, 2001). Selain itu, perusahaan perlu berusaha untuk mengintegrasikan structural capital untuk memperkuat proses dalam organisasi untuk meningkatkan efisiensi operasional perusahaan seperti menurunkan biaya perusahaan serta meningkatkan kemampuan pemecahan masalah (Rehman, Ahmad, Bashir, \& Azeem, 2017). Kerja sama dengan pihak eksternal tidak hanya menyediakan akses ke pengetahuan dan sumber daya mereka, tetapi juga memungkinkan pembagian risiko dan memberikan fleksibilitas yang diperlukan dalam perubahan lingkungan yang terjadi sehingga tingkat relational capital yang lebih tinggi mampu meningkatkan produksi dan efisiensi pemberian layanan serta mengurangi biaya organisasi (Lalović \& Koman, 2018).

Tujuan penelitian dilakukan untuk meneliti dan mengetahui pengaruh human capital, structural capital, dan relational capital terhadap kinerja perusahaan pada perusahaan retail trade yang terdaftar di Bursa Efek Indonesia periode 2014-2018. 


\section{KAJIAN TEORI}

Teori Agensi. Teori agensi menjelaskan tentang hubungan agensi yang terjadi karena adanya kontrak perjanjian antara agent dan principal, di mana agent melakukan tugas-tugas yang sesuai dengan kepentingan principal di mana principal sebagai pemilik modal yang tidak memiliki kemampuan dan keterampilan dalam menjalankan operasi perusahaan, memberikan mandat atau wewenang kepada agent untuk mengambil keputusan yang berkaitan dengan kegiatan operasional perusahaan dan menjalankannya, sesuai dengan perjanjian atau kontrak yang telah disepakati oleh kedua belah pihak (Safriliana, Subroto, Subekti, \& Rahman, 2019). Kedua belah pihak memiliki pendapat dan tujuan yang berbeda, di mana principal berfokus pada peningkatan laba, sedangkan agent mungkin memiliki niat untuk meningkatkan bisnis secara keseluruhan (Mohammed \& Muhammed, 2017).

Teori Stakeholder. Teori pemangku kepentingan percaya bahwa pengembangan perusahaan perlu memperhatikan partisipasi para pemangku kepentingan, dan menekankan pengaruh kemampuan diferensiasi anggota perusahaan terhadap daya saing inti perusahaan (Min, Zhenggang, \& Jing, 2018). Teori stakeholder berbeda dengan teori agensi, di mana teori stakeholder berpendapat bahwa pihak penting dalam perusahaan bukan hanya principal dan agent, melainkan adanya pihak lain yang terlibat seperti pemasok, pelanggan, dan kadangkadang kompetitor (Mohammed \& Muhammed, 2017). Semua pemangku kepentingan, termasuk pemegang saham, telah memberikan beberapa investasi spesifik ke dalam kelangsungan hidup dan pengembangan perusahaan, dan pada saat yang sama, mereka telah berbagi risiko tertentu dalam operasi perusahaan atau telah membayar harga untuk kegiatan perusahaan (Min et al., 2018).

Teori Signalling. Jika dikaitkan dengan perusahaan, adanya asimetri informasi dalam perusahaan memicu sinyal kepada investor atau pihak luar melalui kebijakan manajamen yang menjadi sangat penting dan diharapkan sinyal tersebut memberikan informasi kepada investor tentang bagaimana memandang prospek perusahaan (Puspitaningtyas, 2019). Teori signalling terkait dengan sinyal yang merupakan kebijakan manajemen tentang prospek perusahaan yang akan memberikan manfaat bagi investor sebagai bahan pertimbangan dalam proses pengambilan keputusan investasi (Puspitaningtyas, 2019).

Resource-Based Theory. Resource-Based Theory (RBT) berhubungan dengan gagasan bahwa sumber daya internal perusahaan dapat menjadi sumber langsung bagi keunggulan kompetitif yang berkelanjutan bagi perusahaan (Davis \& Simpson, 2017). RBT melihat bahwa seluruh sumber daya perusahaan bila dikombinasikan dan dimanfaatkan secara tepat, dapat meningkatkan produktivitas dan kinerja perusahaan secara keseluruhan. Ini juga berarti secara lebih umum bahwa sistem, prosedur, kebijakan, struktur dan elemen internal organisasi lainnya harus diorganisir dan diselaraskan sedemikian rupa sehingga mendukung sumber daya internal yang dapat digunakan secara strategis (Davis \& Simpson, 2017).

Kaitan Antar Variabel. Dalam penelitian yang dilakukan oleh Audreylia dan Ekadjaja (2014), ditemukan bahwa variabel human capital efficiency secara parsial berpengaruh secara signifikan terhadap kinerja perusahaan perbankan di Bursa Efek Indonesia yang berarti untuk menjalankan operasi perbankan yang lebih efisien, perusahaan perlu mempertimbangkan sektor sumber daya manusia. Berdasarkan penelitian yang dilakukan 
oleh Susanto (2017) ditemukan bahwa structural capital efficiency memiliki pengaruh yang positif dan signifikan terhadap kinerja perusahaan sehingga semakin tinggi structural capital efficiency, semakin tinggi kinerja perusahaan tersebut. Dalam penelitian Lalović \& Koman (2018), ditemukan bahwa perusahaan yang berkinerja tinggi memiliki relational capital yang tinggi dalam hal yang berkaitan dengan kemampuan perusahaan berelasi dengan pelanggannya dan mengelola persepsi mereka tentang pengakuan publik terhadap merek perusahaan dan citra perusahaan. Dari kaitan antar variabel diperoleh hipotesis sebagai berikut:

H1: $_{1}$ Terdapat pengaruh positif dan signifikan human capital terhadap kinerja perusahaan.

$\mathbf{H}_{2}$ : Terdapat pengaruh positif dan signifikan structural capital terhadap kinerja perusahaan.

H3: Terdapat pengaruh positif dan signifikan relational capital terhadap kinerja perusahaan.

\section{METODOLOGI}

Subjek dalam penelitian ini adalah perusahaan yang terdapat dalam sektor trade, service, and investment dengan sub sektor retail trade yang terdaftar di Bursa Efek Indonesia periode 2014-2018. Objek dalam penelitian ini adalah human capital, structural capital, relational capital, dan kinerja perusahaan di mana 18 perusahaan retail trade yang terdaftar di Bursa Efek Indonesia dijadikan sampel. Analisis ini menggunakan persamaan regresi berganda sebagai berikut:

$\mathrm{ROA}_{i t}=\alpha_{\mathrm{it}}+\beta_{1} \mathrm{HCE}_{\mathrm{it}}+\beta_{2} \mathrm{SCE}_{\mathrm{it}}+\beta_{3} \mathrm{RCE}_{\mathrm{it}}+\varepsilon_{\mathrm{it}}$

Variabel independen meliputi human capital, structural capital, dan relational capital. Human capital diukur dengan HCE (human capital efficiency), yaitu value added (jumlah dari operating profit, employee cost, depreciation, amortization) dibagi dengan human capital (total dana yang diinvestasikan terhadap karyawan dalam hal gaji dan imbalan) (Hamdan, 2018). Menurut Susanto (2017), structural capital dapat dihitung menggunakan SCE (structural capital efficiency) di mana structural capital (value added dikurangi human capital) dibagi dengan value added. Relational capital dapat diukur menggunakan RCE (relational capital efficiency) di mana relational capital (total marketing costs) dibagi dengan value added. Variabel dependen dalam penelitian ini adalah kinerja perusahaan yang diukur dengan ROA (return on assets) yaitu membandingkan net income dengan total assets (Mohammad \& Bujang, 2019).

Teknik analisis data menggunakan software Eviews-9. Uji multikolonieritas digunakan untuk menguji hubungan antara variabel independen (Lestari \& Wicaksono, 2018). Berdasarkan hasil uji multikolonieritas sesuai tabel 1, nilai kolerasi antara HCE dengan SCE sebesar -0.053156, HCE dengan RCE 0.041420, SCE dengan RCE -0.715395. Maka dapat disimpulkan bahwa tidak terdapat nilai kolerasi antara variabel independen yang lebih besar dari $|0,8|$ atau dengan kata lain tidak terjadi multikolonieritas antara variabel independen dalam penelitian. Sehingga, variabel-variabel tersebut layak digunakan dalam penelitian. 
Tabel 1. Uji Multikolonieritas

\begin{tabular}{|c|c|c|c|}
\hline & HCE & SCE & RCE \\
\hline HCE & 1.000000 & -0.053156 & 0.041420 \\
\hline SCE & -0.053156 & 1.000000 & -0.715395 \\
\hline RCE & 0.041420 & -0.715395 & 1.000000 \\
\hline
\end{tabular}

\section{HASIL ANALISIS DATA}

Uji Hipotesis. Uji Hausman dilakukan sebagai lanjutan dari uji Chow untuk menentukan model yang paling tepat untuk digunakan dalam analisis regresi berganda, fixed effect atau random effect (Angesti \& Santioso, 2019). Berdasarkan hasil uji Hausman sesuai tabel 4.6, didapatkan data probabilitas cross-section random sebesar 0.2223 . Hasil tersebut berada di atas $5 \%$ atau 0.05 , maka $\mathrm{H}_{\mathrm{o}}$ diterima dan $\mathrm{H}_{\mathrm{a}}$ ditolak. Oleh karena itu, model yang tepat untuk digunakan adalah model random effect.

Tabel 2. Uji Hausman

Correlated Random Effects - Hausman Test

Equation: Untitled

Test cross-section random effects

\begin{tabular}{|c|r|r|l|}
\hline Test Summary & Chi-Sq. Statistic & Chi-Sq. d.f. & Prob. \\
\hline Cross-section random & 4.390107 & 3 & 0.2223 \\
\hline
\end{tabular}

Sumber: Hasil pengolahan data dengan EViews 9.0

Analisis regresi berganda dilakukan dengan tujuan untuk mengetahui hubungan variabel independen dalam penelitian ini yaitu human capital, structural capital, dan relational capital terhadap variabel dependennya yaitu kinerja perusahaan. Setelah melakukan uji chow yang dilanjutkan dengan uji hausman, hasil menunjukkan bahwa model terbaik yang dapat digunakan dalam penelitian ini adalah random effect. 
Tabel 3. Analisis Regresi Berganda

Dependent Variable: ROA

Method: Panel EGLS (Cross-section random effects)

Date: 11/27/19 Time: 00:29

Sample: 20142018

Periods included: 5

Cross-sections included: 18

Total panel (balanced) observations: 90

Swamy and Arora estimator of component variances

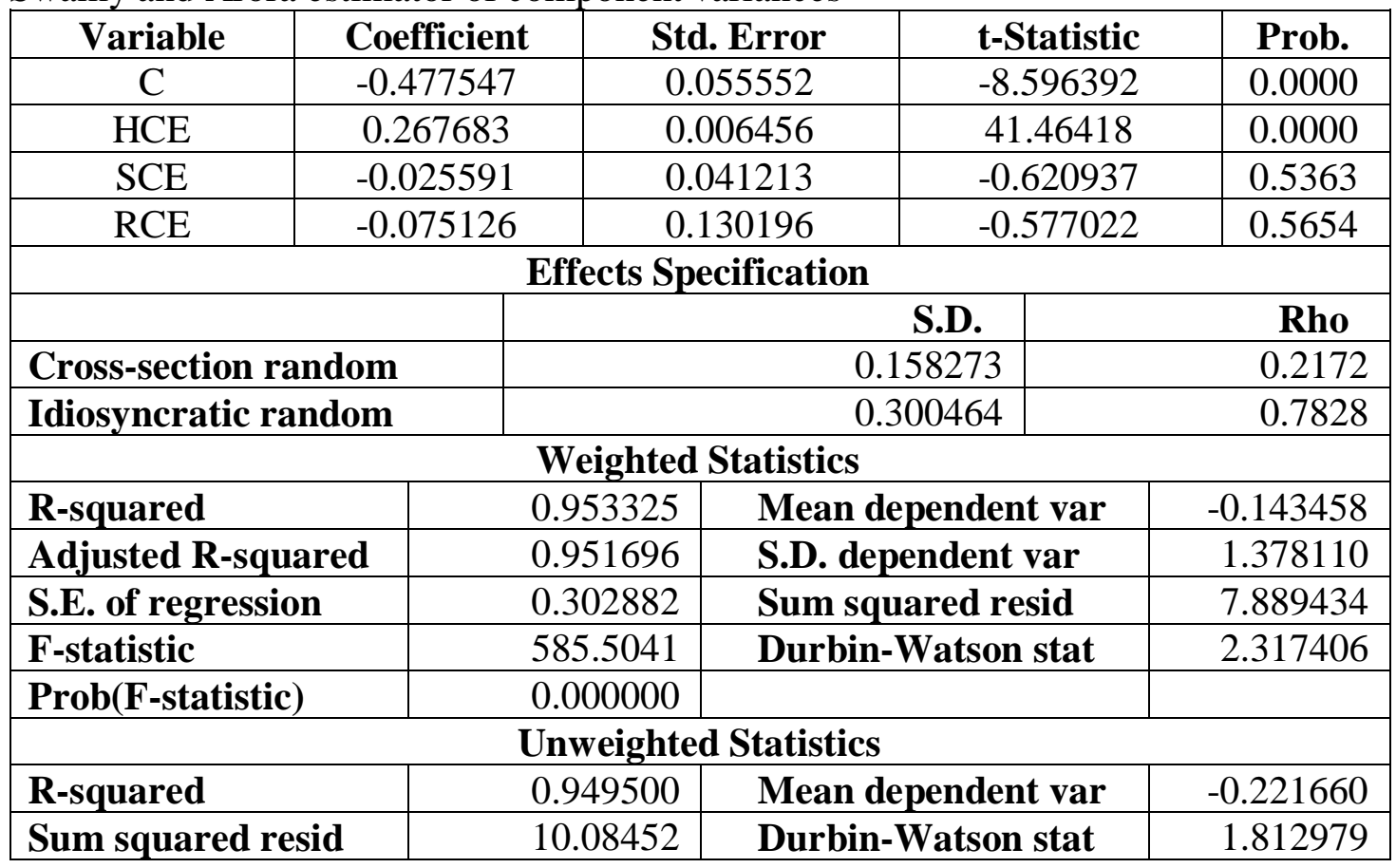

Sumber: Hasil pengolahan data dengan EViews 9.0

Berdasarkan tabel 3, didapatkan data bahwa nilai koefisien regresi variabel konstanta bernilai negatif sebesar -0.477547 , nilai koefisien regresi variabel human capital bernilai positif sebesar 0.267683 dan signifikan terhadap ROA dengan probabilitas sebesar 0.0000 , nilai koefisien regresi variabel structural capital bernilai negatif sebesar -0.02559 dan tidak signifikan terhadap ROA dengan probabilitas sebesar 0.5363 , dan nilai koefisien regresi variabel relational capital bernilai negatif sebesar -0.075126 dan tidak signifikan terhadap ROA dengan probabilitas sebesar 0.5654 .

Uji-F. Uji-F dilakukan untuk mengetahui apakah terdapat pengaruh secara simultan variabel independen (human capital, structural capital, dan relational capital) terhadap variabel dependen (kinerja perusahaan) (Tondi, Samosir, \& Hatane, 2015). Berdasarkan data pada tabel 4.47 diperoleh nilai signifikasi F-statistic sebesar 0.000000, sehingga $\mathrm{H}_{0}$ ditolak dan $\mathrm{H}_{\mathrm{a}}$ diterima. Artinya, variabel independen memiliki pengaruh yang signifikan terhadap variabel dependen secara simultan.

Uji Koefisien Determinasi. Berdasarkan tabel 3, koefisien deteriminasi $R$-squared sebesar 0.953325. Artinya variabel HCE, SCE, dan RCE dapat menjelaskan sebesar 0.953325 atau 
95,33\% variabel ROA, sedangkan sisanya yaitu 4,67\% dijelaskan oleh variabel lain diluar variabel independen dalam penelitian ini.

\section{DISKUSI}

Pada hipotesis pertama, dilakukan pengujian parsial variabel human capital terhadap kinerja perusahaan. Hasil pengujian tersebut menunjukkan bahwa human capital memiliki pengaruh yang positif terhadap kinerja perusahaan retail trade yang terdaftar di Bursa Efek Indonesia periode 2014-2018. Hal ini menjelaskan bahwa peningkatan pada human capital akan berpengaruh pada peningkatan kinerja perusahaan. Hasil pengujian juga membuktikan bahwa human capital memiliki pengaruh yang signifikan terhadap kinerja perusahaan.

Pengelolaan sumber daya manusia yang baik akan menghasilkan kinerja karyawan yang baik. Kinerja karyawan yang baik akan membantu perusahaan dalam mencapai kinerja perusahaan yang optimal. Hal ini dikarenakan kemampuan dan keterampilan karyawan akan mendukung perusahaan dalam meningkatkan kinerjanya. Sebagai contoh inovasi, kreativitas, pengetahuan, kemampuan, keterampilan yang dimiliki oleh berbagai individu yang berbeda-beda di dalam perusahaan, yakni karyawan, akan membantu perusahaan dalam menciptakan nilai (value) perusahaan. Oleh karena itu, dibutuhkan pelatihan dan pendidikan yang tepat, diadakan oleh perusahaan untuk karyawan agar semakin meningkatkan masingmasing aspek tersebut (pengetahuan, keterampilan, dan lain-lain) yang pada akhirnya akan meningkatkan kinerja karyawan. Memperhatikan kesejahteraan karyawan juga merupakan hal yang perlu diperhatikan oleh masing-masing perusahaan karena kepuasan karyawan dan kesejahteraan karyawan akan meningkatkan bahkan memaksimalkan kinerja mereka (sebagai contoh gaji yang sesuai, jam kerja yang sesuai). Pada intinya, perusahaan perlu melihat human capital sebagai modal atau aset yang penting bagi peningkatan kinerja perusahaan. Perusahaan retail trade yang dijadikan sampel dalam penelitian ini sudah menunjukkan bahwa perusahaan-perusahaan ini memanfaatkan human capital secara baik.

Pada hipotesis kedua, dilakukan pengujian parsial variabel structural capital terhadap kinerja perusahaan. Hasil pengujian tersebut menunjukkan bahwa structural capital memiliki pengaruh yang negatif terhadap kinerja perusahaan retail trade yang terdaftar di Bursa Efek Indonesia periode 2014-2018. Artinya jika terjadi peningkatan pada structural capital maka akan berpengaruh pada penurunan kinerja perusahaan. Hasil pengujian juga membuktikan bahwa structural capital tidak memiliki pengaruh yang signifikan terhadap kinerja perusahaan.

Hasil di mana structural capital berpengaruh negatif dan signifikan terhadap kinerja perusahaan terjadi karena adanya kemungkinan asimetri informasi, data error, proses bisnis dan pengaturan tenaga kerja yang salah, dan budaya organisasi yang tidak baik. Sehingga, meskipun perusahaan memiliki informasi dan data yang banyak, proses bisnis yang mungkin sudah tertata, dan memiliki budaya organisasi tersendiri, tidak menjamin bahwa kinerja perusahaan tersebut akan meningkat. Karena perusahaan mungkin tidak menyadari bahwa apa yang mereka miliki merupakan sesuatu yang salah dan belum baik ataupun perusahaan tidak melakukan pemeriksaan dan evaluasi terhadap structural capital secara menyeluruh. Justru apabila aspek-aspek tersebut semakin ditingkatkan, sebagai contoh informasi dan data yang justru salah tetapi perusahaan semakin meningkatkan data tersebut untuk menemukan hasil akhirnya, akan berdampak buruk bagi kinerja perusahaan tersebut. Sebagai contoh lain, perusahaan mempunyai asimetri informasi dan proses bisnis yang kurang tepat bagi perusahaan, peningkatan hal tersebut justru akan menurunkan kinerja perusahaan. Hal ini 
menunjukkan bahwa perusahaan retail trade yang dijadikan sampel belum memiliki proses bisnis yang baik, serta memiliki pengetahuan dan informasi yang belum bisa mendukung usaha karyawan dalam menghasilkan kinerja perusahaan yang optimal.

Pada hipotesis ketiga, dilakukan pengujian parsial variabel relational capital terhadap kinerja perusahaan. Hasil pengujian tersebut menunjukkan bahwa relational capital memiliki pengaruh yang negatif terhadap kinerja perusahaan retail trade yang terdaftar di Bursa Efek Indonesia periode 2014-2018. Artinya jika terjadi peningkatan pada relational capital maka akan berpengaruh pada penurunan kinerja perusahaan. Selain itu, hasil juga menunjukkan bahwa relational capital tidak berpengaruh secara signifikan terhadap kinerja perusahaan.

Berdasarkan hasil pada hipotesis ketiga pada penelitian ini, ditemukan bukti bahwa relasi dengan pihak luar tidak menjamin akan menghasilkan peningkatan terhadap kinerja perusahaan. Justru jika relational capital meningkat, kinerja perusahaan akan menurun. Hal ini dapat terjadi karena target pemasaran yang tidak tepat, cara pemasaran yang kurang tepat, perbedaan kebudayaan yang kuat, perbedaan pemikiran, dan perbedaan visi dan misi dengan pihak luar. Oleh karena itu, apabila relasi tersebut semakin ditingkatkan, justru akan menurunkan kinerja perusahaan. Sebagai contoh, pengeluaran yang semakin bertambah dan perusahaan semakin merugi karena perusahaan melakukan relasi dengan pihak yang tidak menguntungkan bagi pihak perusahaan, tetapi perusahaan tetap melakukan pemasaran atau hubungan terhadap pihak-pihak tersebut bahkan relasi tersebut semakin ditingkatkan, tentu hal tersebut akan mengurangi kinerja perusahaan. Hal ini dapat terjadi karena perusahaan tidak memperhatikan dan melakukan evaluasi yang baik terhadap relational capital yang dimiliki perusahaan sehingga relational capital tersebut justru menurunkan kinerja perusahaan. Berdasarkan hasil analisa yang dilakukan menunjukkan bahwa perusahaan retail trade yang dijadikan sampel belum mampu menciptakan relasi yang baik dengan pihak luar dan belum mampu melakukan pemasaran yang tepat sesuai dengan tujuan perusahaan tersebut sehingga relasi yang dilakukan oleh perusahaan dengan pihak luar justru menurunkan kinerja perusahaan.

\section{PENUTUP}

Berdasarkan pembahasan bab-bab sebelumnya dan hasil penelitian pengaruh human capital, structural capital, dan relational capital terhadap kinerja perusahaan pada perusahaan retail trade yang terdaftar di Bursa Efek Indonesia periode 2014-2018, maka dapat dibuat kesimpulan dari penelitian ini sebagai berikut:

1. Human capital yang diukur dengan HCE memiliki pengaruh yang positif dan signifikan terhadap kinerja perusahaan retail trade yang terdaftar di Bursa Efek Indonesia periode 2014-2018.

2. Structural capital yang diukur dengan SCE memiliki pengaruh yang negatif dan tidak signifikan terhadap kinerja perusahaan retail trade yang terdaftar di Bursa Efek Indonesia periode 2014-2018.

3. Relational capital yang diukur dengan RCE memiliki pengaruh yang negatif dan tidak signifikan terhadap kinerja perusahaan retail trade yang terdaftar di Bursa Efek Indonesia periode 2014-2018.

Saran. Berikut disajikan saran-saran yang dapat diberikan oleh penulis melalui penelitian ini: 
1. Bagi perusahaan untuk lebih memperhatikan pentingnya human capital yang ada di dalam perusahaan. Perusahaan perlu melakukan pelatihan dan pendidikan kepada karyawan serta memperhatikan kesejahteraan karyawan karena kinerja karyawan yang baik akan berdampak positif terhadap kinerja perusahaan. Perusahaan perlu menempatkan karyawan pada departemen yang sesuai dengan keterampilan karyawan yang bersangkutan. Karyawan dengan keterampilan yang sama dijadikan menjadi satu pelatihan yang sama sesuai keterampilan tersebut. Pelatihan juga dilakukan pada setiap departemen perusahaan secara berkelompok untuk meningkatkan kerja sama dalam departemen tersebut, serta kerja sama seluruh departemen secara keseluruhan. Pelatihan perlu dilakukan secara rutin tergantung kebijaksanaan perusahaan (misal sebulan sekali, dua bulan sekali, dll.). Penentuan jam kerja yang sesuai untuk karyawan serta memberikan imbalan yang sesuai dengan kerja karyawan.

2. Bagi investor untuk lebih memperhatikan aspek human capital perusahaan sebagai dasar untul mengambil keputusan investasi.

3. Bagi peneliti selanjutnya untuk mempertimbangkan dalam penambahan variabel lainnya baik itu variabel bebas, variabel mediasi, maupun variabel kontrol lainnya yang belum dipergunakan dalam penelitian ini agar dapat memperluas hasil mengenai faktor-faktor lain yang dapat mempengaruhi kinerja perusahaan. Selain itu, dapat membandingkan variabel-variabel tersebut dengan variabel yang digunakan dalam penelitian ini terkait dengan pengaruhnya dengan kinerja perusahaan.

\section{DAFTAR PUSTAKA}

Angesti, Y. G., \& Santioso, L. (2019). Faktor-Faktor Yang Mempengaruhi Volatilitas Harga Saham Perusahaan Manufaktur. Jurnal Ekonomi, 24(1), 46-64. https://doi.org/10.24912/je.v24i1.450

Audreylia, J., \& Ekadjaja, A. (2014). Pengaruh Modal Intelektual Terhadap Kinerja Perusahaan Perbankan Dengan Ukuran Perusahaan Sebagai Variabel Kontrol. Jurnal Akuntansi, XVIII(10), 286-301.

Davis, P. J., \& Simpson, E. (2017). Resource-Based Theory, Competition and Staff Differentiation in Africa: Leveraging Employees as A Source of Sustained Competitive Advantage. American Journal of Management, 17(1), 19. Retrieved from https://0search-proquest-

com.oasis.unisa.ac.za/docview/1926898178/fulltextPDF/869675928C0B4469PQ/52?a ccountid=14648\&ticket=ST-6016181-Lun7T1QJay7v62PbWbwa7MXMIns-lmkncastc $03 \mathrm{pv}$

Hamdan, A. (2018). Intellectual capital and firm performance: Differentiating between accounting-based and market-based performance. International Journal of Islamic and Middle Eastern Finance and Management, 11(1), 139-151. https://doi.org/10.1108/IMEFM-02-2017-0053

Kanchana, N., \& Mohan, P. R. R. R. (2017). a Review of Empirical Studies in Intellectual Capital and Firm Performance. Indian Journal of Commerce \& Management Studies, VIII(1), 52-58. https://doi.org/10.18843/ijcms/v8i1/08

Khan, M. T., Humayun, A. A., \& Sajjad, M. (2015). Connotation of " Human Capital : Concept, Effects and Benefits ( Review ) Origin of Concept of Human Capital. International Journal of Information, Business and Management, 7(1), 19-36.

Kumar, S., Colombage, S., \& Rao, P. (2017). Research on capital structure determinants: a review and future directions. International Journal of Managerial Finance, 13(2), 106- 
132. https://doi.org/10.1108/IJMF-09-2014-0135

Lalović, G., \& Koman, M. (2018). Do Better Performing Companies Possess More Intangible Assets: Case of Slovenia *. Economic and Business Review, 20(1), 5-50. https://doi.org/10.15458/85451.59

Lestari, D., \& Wicaksono, B. W. (2018). Kinerja Perusahaan Ditinjau Dari Faktor Non Keuangan Dan Struktur Modal. Jurnal Ekonomi, 23(3), 389. https://doi.org/10.24912/je.v23i3.420

Mantari, J. S., \& Nuryasman, M. (2017). Moderation Effect of Exchange Rate to Signaling Theory Validity in Indonesia Stock Exchange. Business and Management Studies, 3(1), 80. https://doi.org/10.11114/bms.v3i1.2259

Min, Z., Zhenggang, C., \& Jing, L. (2018). Stakeholder Theory Based on Information Field Model. Advances in Management \& Applied Economics, 8(3), 11-26.

Mohammad, H. S., \& Bujang, I. (2019). Performance of Malaysian Financial Firms: An Intellectual Capital Perspective Using MVAIC Model. Asian Economic and Financial Review, 9(7), 752-765. https://doi.org/10.18488/journal.aefr.2019.97.752.765

Mohammed, S. A. S. A.-N., \& Muhammed, J. (2017). The relationship between agency theory, stakeholder theory and Shariah supervisory board in Islamic banking: An attempt towards discussion. Humanomics, 33(1), 75-83. https://doi.org/10.1108/H-082016-0062

Nuryasman, M. (2001). Peningkatan Kualitas Sumber Daya Manusia Melalui Problem-Based Learning ( PBL ) Problem-Based Learning Sebagai Salah Satu Sarana Peningkatan Kualitas Sumber Daya Manusia. Jurnal Manajemen, 5(2), 89-97.

Puspitaningtyas, Z. (2019). Empirical evidence of market reactions based on signaling theory in Indonesia Stock Exchange. Investment Management and Financial Innovations, 16(2), 66-77. https://doi.org/10.21511/imfi.16(2).2019.06

Rehman, W. U., Ahmad, A., Bashir, F., \& Azeem, S. (2017). Intellectual Capital Driven Performance: Role of Innovative Performance and Business Process. Pakistan Economic and Social Review, 55(1), 223-246.

Safriliana, R., Subroto, B., Subekti, I., \& Fuad Rahman, A. (2019). Overviewd of Contracting Theory \& Agency Theory: Determinants Public Accounting Firms Switching on Voluntary. International Journal of Organizational Innovation, 11(3), 10-21. https://doi.org/10.18502/kss.v3i10.3381

Susanto, L. (2017). Intellectual Capital and Firm Performance. International Journal of Economic Perspectives, 11(1), 1621-1631.

Tondi, T., Samosir, B., \& Hatane, E. (2015). Pengaruh Human Capital Efficiency, Relational Capital Efficiency, Capital Employed Efficiency, Dan Situasi Krisis Ekonomi Global Terhadap Non Performing Loans, Perusahaan Perbankan Di Indonesia Tahun 20072015. Business Accounting Review, 5(2), 49-62. 